\title{
GAMBARAN TINGKAT PENGETAHUAN IBU TENTANG PENYAKIT KANKER SERVIKS DI WILAYAH JAKARTA TIMUR
}

\author{
Suryani Hartati ${ }^{1}$, Retno Winarti ${ }^{2}$ \\ ${ }^{1.2}$ Dosen Akademi Keperawatan Hermina Manggala Husada \\ E-mail : suryanihartati4@gmail.com
}

\begin{abstract}
Abstrak
Angka kematian kanker serviks masih tinggi, lebih dari 92 ribu perempuan di Indonesia diantaranya karena kanker serviks, sehingga menempati nomor dua dalam jumlah tertinggi di dunia. hal ini dapat disebabkan karena tidak adanya proses pemantauan sejak dini. Cakupan dektesi dini kanker serviks di Indonesia sangat rendah yang hanya berkisar 5\%. Hal ini disebabkan oleh kurangnya pengetahuan tentang kanker serviks sehingga angka kejadian kanker serviks meningkat setiap tahunnya. Tujuan: Untuk menggambarkan tingkat pengetahuan ibu tentang kanker serviks pada ibu berusia antara 30 hingga 50 tahun di wilayah Jakarta Timur. Metode: Penelitian cross-sectional ini menggunakan teknik consecutive sampling untuk memilih 103 ibu di Jakarta Timur. Penelitian ini telah dilakukan dari bulan Juni hingga Agustus 2019. Data dikumpulkan menggunakan kuesioner yang terdiri dari karakteristik ibu dan tingkat pengetahuan ibu tentang kanker serviks. Telah diuji validitas dan reliabilitasnya. Uji validitas menggunakan product moment Pearson ( $\mathrm{r}=0,467-948)$, dan uji reliabilitas dengan Cronbach Alpha (0,794).Hasil: penelitian menunjukkan bahwa sebagian besar ibu memiliki pengetahuan rendah $(75,7 \%)$. Hasil penelitian membuktikan bahwa ada hubungan antara tingkat pendidikan dengan pengetahuan tentang kanker serviks $(\mathrm{p}=$ 0,000). Usia, status perkawinan, pekerjaan, suku tidak memiliki hubungan dengan pengetahuan tentang kanker serviks. Saran yang dapat peneliti berikan ialah perawat dalam memberikan penyuluhan tentang kanker serviks pada ibu, harus melihat latar belakang tingkat pendidikan ibu, sehingga ibu paham terhadap ilmu yang diterima.
\end{abstract}

Kata kunci: kanker serviks, pendidikan, pengetahuan

\begin{abstract}
The cervical cancer mortality rate is still high, more than 92 thousand women in Indonesia among them due to cervical cancer, making it number two in the highest number in the world. this can be caused by the absence of an early monitoring process. Coverage of early cervical cancer coverage in Indonesia is very low, only around 5\%. This is due to lack of knowledge about cervical cancer so that the incidence of cervical cancer increases every year. Objective: To describe mother's knowledge level about cervical cancer in mothers age between 30 to 50 years in east Jakarta area. Method: This cross-sectional study applied a consecutive sampling technique to select 103 mothers in east Jakarta. This study had been conducted from june up August 2019. Data collected using questionnaire which consisted of mothers' characteristic and mother's knowledge level about cervical cancer. It has been tested for validity and reliability. The validity test using the Pearson product moment $(r=0,467-948)$, and reliability test with Cronbach Alpha (0.794). Result : the study showed that most of the mothers had low knowledge (75.7\%). The results of the study proved that there is a relation between the level of education with knowledge about cervical cancer $(p=0.000)$. Age, marital status, occupation, ethnicity have no relation with knowledge about cervical cancer Suggestions that researchers can give are nurses in providing counseling about cervical cancer to mothers, should look at the background level of mother's education so that mothers understand the knowledge received
\end{abstract}

Keywords: cervical cancer, education, knowledge

\section{PENDAHULUAN}

Kanker serviks merupakan penyakit kanker

yang paling banyak diderita dan

meyebabkan kematian pada perempuan.
Kejadian kanker serviks di Asia lebih tinggi

bila dibandingkan dengan kanker ovarium

dan kanker payudara (Riley, Dobson,

Elizabeth \& Kirst, 2013; Singh, Azuine \& 
Siahpush, 2012). Sejumlah $\quad 500.000$ perempuan setiap tahunnya didiagnosa kanker serviks (Riley, Dobson, Jonesn \& Kirst 2013; Spencer, 2007). Kanker serviks merupakan penyebab kematian yang kedua pada perempuan negara berkembang yang terjadi sekitar 78\% (Greer, et al, 2010)

Pada tahun 2017 ini diprediksikan hampir 9 juta orang meninggal di seluruh dunia akibat kanker dan akan terus meningkat hingga 13 juta orang per tahun di 2030. Di Indonesia, prevalensi penyakit kanker juga cukup tinggi. Menurut data Riskesdas 2013, prevalensi kanker di Indonesia adalah 1,4 per 100 penduduk atau sekitar 347.000 orang. Sedangkan jika melihat data BPJS Kesehatan, terdapat peningkatan jumlah kasus kanker yang ditangani dan pembiayaannya pada periode $2014 / 2015$ ( Depkes, 2017).

Penderita kanker serviks di Asia terbanyak dengan jumlah 18,9 per 100.000 terdapat di Negara Vietnam sedangkan terendah dengan jumlah 4,5 per 100.000 di India/Pakistan (Wang, Carreon, Gomez \& Devesa, 2010). Indonesia merupakan negara urutan kesepuluh di Asia, dengan penderita kanker serviks sebanyak $28,6 \%$ dari seluruh perempuan (Tjindarbumi \& Mangunkusumo, 2002; POI, 2010).

Sampai tahun 2014, program deteksi dini kanker payudara dan kanker leher rahim telah berjalan pada 1.986 Puskesmas di 304 kabupaten/kota yang berada di 34 provinsi di Indonesia. Cakupan deteksi dini kanker leher rahim dan payudara masih rendah, yaitu sebesar $2,45 \%$, sehingga memerlukan upaya lebih kuat untuk mencapai target. yaitu deteksi dini terhadap 50\% perempuan usia 30-50 tahun selama 5 tahun (Rakesda, 2017). Namun, cakupan dektesi dini kanker serviks di Indonesia sangat rendah yang hanya berkisar 5\%. Hal ini disebabkan oleh kurangnya pengetahuan tentang kanker serviks sehingga angka kejadian kanker serviks meningkat setiap tahunnya. Pengetahuan yang baik diharapkan dapat memunculkan kesadaran untuk dapat melakukan pemeriksaan dini kanker serviks. Tidak hanya pengetahuan, sikap yang baik juga diperlukan untuk dapat melakukan tindakan skrining dan deteksi dini (Tilusari, 2014).

Keadaan umum dan lingkungan di Propinsi DKI Jakarta masih kurang mendukung untuk tercapainya derajat kesehatan masyarakat yang optimal, mengingat 
kepadatan penduduk yang tidak merata dan kepadatan hunian yang cukup tinggi lebih dari seperempat atau sekitar $28 \%$ penduduk tinggal di wilayah Jakarta Timur. Provinsi DKI Jakarta, jumlah kematian ibu terbanyak secara berurutan ada di wilayah Jakarta Timur dan Jakarta Barat ( Profil DKI,2018).

\section{TINJAUAN TEORI}

Kanker serviks merupakan neoplasma ganas yang menyerang pada sel skuomosa serviks dengan melalui tahapan yang lama sebelum menjadi karsinoma invansive yang terinfeksi oleh persistent human papillomavirus (HPV) dan ditularkan melalui mikro lesi atau sel abnormal dari vagina saat berhubungan seksual (spencer, 2007; POI, 2010; Andrijono, 2012). Penyebab utama kanker serviks adalah Infeksi dari HPV (Ali, Kuelker \& Wassie, 2012). HPV tipe 18 dan HPV tipe 16 paling banyak menyebab kanker serviks yaitu sebesar $70 \%$ pada perempuan yang terkena kanker serviks di
Indonesia dan Asia (Andrijono, 2012; Spencer, 2007; Ali, Kuelker \& Wassie, 2012).

Kanker serviks menimbulkan beberapa gejala umum keluar darah atau nyeri selama hubungan seksual, keluar darah diantara siklus menstruasi dan pengeluaran yang tidak biasa dari vagina. Pada stadium lanjut disertai dengan adanya cairan yang keluar berbau tak sedap, nyeri pelviks, lumbosacral dan gluteus, nyeri didaerah kandung kemih dan rectum disertai gangguan berkemih (Spencer, 2007; POI, 2010; Desen, 2008). Perubahan gejala yang ditimbul pada stadium awal dan stadium lanjut dijelaskan pada gambar 2.1. Pendarahan, keputihan dan nyeri merupakan gejala yang paling sering dikeluhkan oleh pasien kanker serviks. Pendarahan yang terjadi pada pasien kanker serviks disebabkan karena eksfoliasi jaringan kanker (Desen, 2008). Pendarahan pada stadium awal terjadi karena periksa dalam atau pasca koitus.

Tabel 1

Stadium kanker serviks

\begin{tabular}{lll}
\hline \multicolumn{1}{l}{ Stage I } & Karsinoma masih terbatas di serviks \\
\hline IA & $\begin{array}{l}\text { Invasi hanya dapat dikenali secara mikroskopis. Kedalam invasi ke stroma } \\
\text { tidak lebih dari } 5 \mathrm{~mm} \text { dan lebar lesi tidak lebih dari } 7 \mathrm{~mm}\end{array}$ \\
\hline & IA1 & Invasi stroma dengan kedalaman $\leq 3 \mathrm{~mm}$ dan lebar $\leq 7 \mathrm{~mm}$ \\
\hline & IA2 & Invasi stroma dengan kedalaman $>3 \mathrm{~mm}$ dan $<5 \mathrm{~mm}$ serta lebar $>7 \mathrm{~mm}$ \\
\hline IB & Lesi terbatas di serviks atau secara mikroskopis lebih dari stadium I A \\
\hline & IB1 & Besar lesi klinis tidak lebih dari $4 \mathrm{~cm}$ \\
\hline & IB2 & Besar lesi klinis lebih besar dari $4 \mathrm{~cm}$ \\
\hline Stage II & Tidak melibatkan vagina, tetapi belum mencapai $1 / 3$ bawah atau infiltrasi ke \\
\hline
\end{tabular}




\begin{tabular}{|c|c|}
\hline & parineum tetapi belum mencapai dinding pinggul \\
\hline \multicolumn{2}{|r|}{ (2) } \\
\hline IIA1 & Lesi $\leq 4 \mathrm{~cm}$ dari diamter terbesar \\
\hline IIA2 & Lesi $>4 \mathrm{~cm}$ diameter terbesar \\
\hline IIB & Infiltrasi ke parametrium tetapi belum mencapai panggul \\
\hline Stage III & $\begin{array}{l}\text { Telah melibatkan 1/3 bawah vagina atau adanya perluasan ke panggul. } \\
\text { Hidromefrosis atau gangguan fungsi ginjal termasuk dalam stadium ini, } \\
\text { kecuali kelainan ginjal dapat diklienktikan oleh sebuang air besar lain. }\end{array}$ \\
\hline IIIA & $\begin{array}{l}\text { Keterlibatan } 1 / 3 \text { bawah vagina dan infiltrasi paramentrium belum mencapai } \\
\text { panggul }\end{array}$ \\
\hline IIIB & $\begin{array}{l}\text { Perluasan sampai dinding panggul atau adanya hidronefrosis atau gangguan } \\
\text { fungsi ginjal }\end{array}$ \\
\hline Stage IV & Perluasan ke organ reproduksi \\
\hline IVA & Keterlibatan makosa kandung kemih atau mukosa rektum \\
\hline IVB & Metastase jauh telah keluar dari rongga panggul \\
\hline
\end{tabular}

Sumber: FIGO (2009); POI (2010); Spencer (2007)

Pengetahuan merupakan tingkat perilaku masyarakat dalam melakukan pencegahan dan melaksanakan pengobatan dan perilaku yang disarankan oleh tenaga kesehatan (dokter, perawat, bidan) atau orang lain. Pengetahuan merupakan domain yang sangat penting untuk terbentuknya perilaku seseorang. Pengetahuan yang harus dimiliki oleh masyarakat di wilayah Jakarta Timur

\section{METODOLOGI}

Desain penelitian ini menggunakan penelitian cross-sectional ini menggunakan teknik consecutive sampling yang dilakukan untuk mengetahui nilai variabel mandiri, baik satu variabel atau lebih (independen) tanpa membuat perbandingan, atau menghubungkan antara variabel satu dengan variabel yang lain. Populasi dalam penelitian meliputi arti penyakit kanker seerviks, penyebab, gejala yang sering menyertai dan pentingnya melakukan deteksi dini yang teratur dan terus-menerus dalam jangka panjang serta mengetahui bahaya yang ditimbulkan dari penyakit kanker serviks dimulai dari tingkatan tahu, paham, aplikasi, analisa, sintesis dan evaluasi seputar penyakit kanker serviks.

ini adalah perempuan / ibu ibu yang ada di wilayah Jakarta Timur.. Penelitian telah dilakukan sejak bulan Juni sampai dengan bulan Agustus 2019 Di Puskesmas Wilayah Jakrta Timur dengan sampel sebanyak 103 responden. Adapun kriteria inklusi pada penelitian ini adalah:Perempuan/ ibu ibu yang berusia 30-50 tahun. 
Tempat penelitian ini adalah di puskesmas wilayah Jakarta Timur, telah mendapatkan ijin rekomendasi penelitian dari Unit Pelaksana Pelayanan Terpadu Satu Pintu(PTSP) Kota Administrasi Jakarta Timur No. 1413/Af.1/31-75/-1.862.9/2019 Penelitian ini dilakukan pada bulan Juni sampai Agustus tahun 2019. Prinsip etik yang diterapkan pada penelitian ini telah disetujui dan dinyatakan lolos uji etik oleh komite etik penelitian kesehatan Fakultas Kedokteran Universitas Indonesia No. KET615/UN2.F1/ETIK/PPM.00.02/2019. Alat pengumpul data menggunkan kuesioner yang berisi isian data karakteristik ibu. Data karakteristik ibu terdiri dari usia ibu, pekerjaan, tingkat pendidikan, status pernikahan, pengalaman pernah menderita kanker serviks, latar belakang social budaya, pernah mendengar penyakit kanker serviks di media informasi. Sedangkan instrumen yang digunakan untuk mengetahui tingkat pengetahuan pertanyaan terkait seputar penyakit kanker serviks. Peneliti mengaplikasikan pertanyaan terdiri dari 10 poin pernyataan terbuka tentang pengetahuan dengan pilihan jawaban. Kuesioner ini sudah dilakukan uji validitas dan reabilitas dengan menggunakan Pearson Product Moment, hasil uji validitas menyatakan bahwa nilai $r$ hitung untuk soal 3 lebih rendah dari $\mathrm{r}$ tabel sehingga dikatakan no 3 dianulir sehingga total soal adalah 10 .

Penelitian ini menggunakan analisis univariat masing-masing variabel independen, dependen dan confounding dideskripsikan berdasarkan jenis data variabel. Pada penelitian ini untuk variabel independen yaitu Usia, tingkat pendidikan, pekerjaan, status pernikahan, pengalaman, social budaya,media informasi. Variabel dependen yaitu menjelaskan tentang gambaran tingkat pengetahuan ibu / perempuan yang ada di wilayah Jakarta Timur. Analisa bivariat yang dilakukan terhadap dua variabel yang diduga berhubungan atau berkorelasi. Analisa yang digunakan dalam penelitian ini menggunakan spearmen rank

\section{HASIL ANALISIS DAN PEMBAHASAN}

\section{Analisis univariat}

Distribusi responden berdasarkan kategori umur, pekerjaan, pendidikan, penderita, suku, dan pengetahuan dapat dilihat pada tabel 2 sebagai berikut: 


\section{Tabel 2}

Distribusi Responden Berdasarkan usia,status pernikahan, pekerjaan, pendidikan, penderita, suku, dan pengetahuan di wilayah Jakarta timur tahun $2019(\mathrm{n}=103)$

\begin{tabular}{|c|c|c|}
\hline Variabel & Jumlah & Persentase $(\%)$ \\
\hline $\begin{array}{l}\text { Usia } \\
30-35 \\
36-40 \\
41-50\end{array}$ & $\begin{array}{l}23 \\
50 \\
30\end{array}$ & $\begin{array}{l}22.3 \\
48.54 \\
29.1\end{array}$ \\
\hline $\begin{array}{l}\text { Status pernikahan } \\
\text { Nikah } \\
\text { Janda }\end{array}$ & $\begin{array}{l}93 \\
10\end{array}$ & $\begin{array}{l}90.29 \\
9.7\end{array}$ \\
\hline Pekerjaan & & \\
\hline $\begin{array}{l}\text { Tidak bekerja } \\
\text { bekerja }\end{array}$ & $\begin{array}{c}71 \\
32\end{array}$ & $\begin{array}{c}68.9 \\
31.1\end{array}$ \\
\hline $\begin{array}{l}\text { Pendidikan } \\
\text { SD }\end{array}$ & & \\
\hline $\begin{array}{l}\text { SMP } \\
\text { SMA } \\
\text { PT } \\
\text { Penderita }\end{array}$ & $\begin{array}{l}31 \\
50 \\
12 \\
10\end{array}$ & $\begin{array}{c}30.1 \\
48.5 \\
11.7 \\
9.7\end{array}$ \\
\hline Tidak & & \\
\hline Ya & $\begin{array}{r}92 \\
9\end{array}$ & $\begin{array}{r}89.3 \\
8.7\end{array}$ \\
\hline $\begin{array}{l}\text { Suku } \\
\text { Jawa }\end{array}$ & & \\
\hline Luar jawa & 100 & 97.1 \\
\hline $\begin{array}{l}\text { Pengetahuan } \\
\text { Kurang }\end{array}$ & 3 & 2.9 \\
\hline Cukup & $\begin{array}{l}78 \\
25 \\
\end{array}$ & $\begin{array}{l}75.7 \\
24.3 \\
\end{array}$ \\
\hline
\end{tabular}

\section{Pada tabel 2}

Karateristik responden berdasarkan dari usia ibu di wilayah puskesmas Jakarta Timur paling banyak usia 3640 tahun dengan prosentase 48,54\%, dibandingkan pada usia 30-35 tahun dengan prosentase $22.3 \%$ dan usia 41-
50 tahun dengan prosentase 29,1\%. Karakteristik status pernikahan yang menikah lebih banyak 93 orang dengan prosesntase 90,9 \% dibandingkan yang status janda sebesar 9,7\%. karakteristik pekerjaan, 
lebih banyak ibu yang tidak bekerja dengan prosentase $68.9 \%$ dibandingkan dengan ibu yang bekerja sebanyak $31.1 \%$. Karakteristik tingkat pendidikan pada ibu lebih banyak SMP dengan prosentase $48.5 \%$ dibandingkan SD sebanyak $30.1 \%$, SMA sebanyak11.7 \%, Perguruan Tinggi sebanyak $9.7 \%$. Berdasarkan pengalaman/ penderita pernah menderita kanker serviks lebih sedikit sebesar $8.7 \%$ dibandingkan yang belum pernah menderita sebanyak $89,3 \%$. Karakteriktik Suku atau latar belakang social budaya lebih banyak suku jawa sebanyak 97,1 \% dibandingkan di luar jawa sebesar 2.9 $\%$, Karakteristik pengetahuan penyakit kanker serviks lebih banyak yang kurang tahu sebesar 75,7 \% dibandingkan yang cukup tahu sebanyak $24,3 \%$

\section{b.Analisis Bivariat}

Korelasi/ hubungan usia ibu, status pernikahan, pekerjaan, pendidikan, penderita, suku, dan pengetahuan dengan tingkat pengetahuan (analisis bivariat)

Analisis ini bertujuan untuk mengetahui hubungan masing-masing karakteristik ibu dengan tingkat pengetahuan di puskesmas di wilayah Jakarta Timur. Gambaran hubungan tersebut dapat dilihat pada tabel 3

\section{Tabel 3}

Hubungan pengetahuan dengan usia,status pernikahan, pekerjaan, pendidikan, penderita, suku, dan pengetahuan di wilayah Jakarta timur tahun $2019(\mathrm{n}=103)$

\begin{tabular}{lcc}
\hline \multicolumn{1}{c}{ Variabel } & $\mathrm{r}$ & P Value \\
\hline 1.Umur & 0.325 & 0.098 \\
2.Status Pernikahan & 0.867 & 0.045 \\
3. Pekerjaan & 0.909 & 0.011 \\
4. Pengetahuan & 0.000 & 0.457 \\
5. Penderita & 0.053 & 0.191 \\
6. Suku & 0.324 & -0.098 \\
7. Pengetahuan & - & 1.000 \\
\hline
\end{tabular}

Hasil penelitian menunjukan bahwa ada hubungan antara tingkat pendidikan dengan pengetahuan tentang kanker serviks dengan nilai $\mathrm{r}=0.000$ lebih lecil dari 0.05 . 
sedangkan usia responden tidak berhubungan dengan pekerjaan, suku dan menderita kanker tidak ada hubunganya dengan pengetahuan tentang kanker serviks karena memiliki nila $r$ yang lebih besar dari 0,05 artinya tingkat pendidikan mememiliki hubungan yang lebih besar dibandingkan dengan karakteristik lain seperti usia, status pernikahan, pekerjaan, pendidikan, penderita, suku, dan pengetahuan .

\section{PEMBAHASAN}

\section{Karakteristik ibu}

Karakteristik responden yang dibahas dalam penelitian ini adalah usia,status pernikahan, pekerjaan, pendidikan, penderita, suku, dan pengetahuan. Pemilihan variabel karakteristik yang ditanyakan terhadap responden disesuaikan dengan penelitian sebelumnya yang mencantumkan data karakteristik berdasarkan pada usia,status pernikahan, tingkat pendidikan dan pengetahuan.

Setiap tahunnya, terdapat 500.000 kasus baru carcinoma cervicis uteri dan lebih dari 250.000 kematian di dunia. Carcinoma cervicis uteri sering dihubungkan dengan faktor intrinsik dan ekstrinsik. Faktor instrinsik adalah yang berhubungan dengan sosiodemografi seseorang misalnya genetik, suku / ras, usia, status perkawinan, tingkat pendidikan, dsb. Sedangkan faktor ekstrinsik antara lain bahan karsinogen, virus HPV, tingginya paritas, gaya hidup, rokok, dsb Hanif Alienda Wardhani, Siti Moetmainnah, Noor Yazid, 2014.

Hasil penelitian menunjukkan mayoritas ibu ibu yang ada di wilayah Jakarta timur berada pada usia 36-40 tahun sebanyak 50 orang dengan presentase 48,54\%. Usia 35-40 tahun wanita berada pada batasan usia beresiko. Di usia ini ibu memiliki resiko terkena penyakit ca cerviks, karena sudah sering melakukan aktivitas seksual sehingga ibu diharapkan memperhatikan kondisi tubuhnya agar selalu dalam kondisi prima dan bugar agar terhindar dari berbagai macam penyakit.

Status pernikahan lebih banyak yang sudah menikah sebanyak 93 orang dengan prosentase $90,9 \%$ dibandingkan dengan janda dan yang masih gadis. Ibu ibu yang ada di wilayah Jakarta timur banyak yang tidak bekerja sebanyak 71 orang dengan prosentase $68,9 \%$ dibandingkan ibu yang bekerja sebanyak $31.1 \%$. Suku atau latar belakang social budaya lebih banyak suku jawa sebanyak 100 orang $(97,1 \%)$ dibandingkan di luar jawa sebesar 3 orang $(2.9 \%)$.Berdasarkan pengalaman/ penderita 
pernah menderita kanker serviks lebih sedikit sebesar 9 orang $(8.7 \%$ )dibandingkan yang belum pernah menderita sebanyak 92 orang $(89,3 \%)$ dilatar belakangi pendidikan SMP sebanyak 50 orang dan ibu ibu memiliki pengetahuan yang kurang tahu tentang penyakit kanker serviks lebih banyak sebesar 78 orang $(75,7$ $\%$ )dibandingkan yang cukup tahu sebanyak 25 orang $(24,3 \%)$. Tingkat pendidikan seseorang dapat menentukan kemampuan intelektual, pemahaman dan kemampuan berpikir kritis dan logis seseorang dalam mengolah informasi dan mengambil keputusan dalam bertindak. Tetapi tingginya tingkat pendidikan seseorang tanpa diikuti kemauan belajar, tidak menjamin seseorang untuk memiliki tingkat pengetahuan yang baik, sebaliknya orang lain yang mau belajar dan menambah pengetahuannya dengan informasimeskipun latar belakang tingkat pendidikannya rendah dapat memiliki pengeta Hasil penelitian ini mengkorfirmasi penelitian - penelitian sebelumnya yang menyatakan bahwa dari 110 responden, kelompok terbesar responden berusia 41-55 tahun $(18,2 \%)$ dan berpendidikan tinggi $(36,4 \%)$ dan menyatakan bahwa tingkat pengetahuan ibu yang berusia 21-55 tahun mengenai pemeriksaan Pap smear berada dalam kelompok sedang, yaitu sebesar
62,7\% Octavia, Chintami, 2009. Prilaku adalah suatu kegiatan atau aktivitas organisme atau makhluk hidup yang bersangkutan. Setiap WUS perlu melakukan pencegahan terhadap kanker serviks, karena pada usia tersebut dapat beresiko terjadi kanker serviks. Perilaku terbentuk di dalam diri seseorang dari dua faktor utama yaitu stimulus dan respon (Notoatmodjo, 2005). Dimana stimulus merupakan faktor dari luar diri seseorang (faktor eksternal), dan respon merupakan faktor dari dalam diri seseorang (faktor internal). Faktor eksternal dan internal inilah yang mempengaruhi seseorang untuk berperilaku terhadap pencegahan kanker serviks.

\section{Hubungan karakteristik ibu dengan pengetahuan penyakit kanker serviks}

Usia merupakan faktor yang berkontribusi pada gambaran umum hasil reproduksi pada seorang wanita. Ibu berusia 36-40 tahun termasuk katogori ibu berusia tua dan tidak reproduksi yang kemungkinan beresiko terkena penyakit kanker serviks karena seringnya aktivitas seksual. Hasil penelitian Fisyal Herlana, Ismet M. Nur, Wida Purbaningsih, 2017 menyatakan bahwa jumlah penderita kanker serviks yang didiagnosis secara histopatologi di RSUD Al-Ihsan Bandung pada periode ini adalah 
82 orang. Sebagian besar ditemukan pasien kankers serviks dengan karakteristik usia $>35$ tahun sebanyak 71 orang $(86,6 \%)$, paritas $\geq 3$ sebanyak 52 orang $(63,4 \%)$, dan gambaran histopatologi karsinoma sel skuamosa sebanyak 58 orang (70,7\%). Simpulan, frekuensi tertinggi kanker serviks terjadi pada usia $>35$ tahun, paritas $\geq 3$, dan gambaran histopatologi terbanyak karsinoma sel skuamosa. Kanker leher rahim (kanker serviks) merupakan sebuah tumor ganas yang tumbuh didalam rahim atau serviks yang dapat terjadi pada wanita usia 35- 55 tahun Hasil penelitian ini menunjukkan bahwa paling banyak usia ibu adalah 36-40 tahun untuk dapat diberikan motivasi dan pengetahuan dalam pemberian informasi tentang penyakit kanker serviks , tetapi dilihat dari hubungan usia dengan pengetahuan ibu tentang penyakit kanker serviks tidak ada hubungannya, hal ini sependapat dengan hasil penelitian Hidayat, Hasibuan , Fitriyati, 2014 menyatakan bahwa pasien kanker serviks lebih banyak pada usia lebih dari 50 tahun, sementara insidensi tertinggi pasien yang terdiagnosis kanker servik di Amerika adalah pada rentang usia 40 sampai 49 tahun. Semakin muda dan semakin tua semakin tidak berisiko terkena kanker serviks da tidak ada hubungannya usia dengan pengetahuan.
Hasil uji statistik variabel status pernikahan menunjukkan bahwa tidak ada hubungan antara status pernikahan dengan pengetahun ibu . Hasil penelitian menunjukkan banyaknya ibu yang sudah menikah dan tidak bekerja dan tidak ada hubungannya yang lebih besar dengan penyakit kanker serviks, disimpulkan bahwa ibu yang status pernikahannya sudah menikah dibanding yang belum dan janda tidak memiliki hubungan dengan pengetahuan penyakit kanker serviks, hal ini sejalan dengan hasil penelitian Wardhani, Moetmainnah,Yazid, 2012 menyatakan bahwa dari 124 pasien yang diteliti, yang menderita carcinoma cervicis, diketahui bahwa variabel yang berhubungan dengan kejadian carcinoma cervicis adalah paritas $(\mathrm{p}=0,013)$. Sedangkan variabel yang tidak berhubungan dengan dengan kejadian carcinoma cervicis uteri adalah umur $(\mathrm{p}=0,591)$ dan status perkawinan $(\mathrm{p}=0,649)$.

Hasil uji statistik variabel pekerjaan menunjukkan bahwa tidak ada hubungan antara pekerjaan dengan pengetahuan penyakit kanker serviks. Hasil penelitian menunjukkan banyaknya ibu yang tidak bekerja tidak ada hubungannya terhadap pengetahunnya,dan dihubungkan juga status ekonomi dalam keluarga. Pekerjaan 
berpengaruh terhadap pengetahuan, wawasan, pemahaman, dan daya tangkap terhadap informasi yang diperoleh berdasarkan pengalaman dan latar belakang pekerjaannya. Pekerjaan yang dilakukan seseorang akan mempengaruhi pola pikir terhadap suatu tindakan yang akan dilakukan. Seseorang yang memiliki pekerjaan di luar rumah tentunya akan banyak memiliki tingkat sosial yang lebih tinggi dibandingkan seseorang yang tidak bekerja atau berdiam diri di rumah. Pengetahuan-pengetahuan pun akan datang pula saat melakukan pekerjaan di luar rumah. Sedangkan seseorang yang tidak bekerja mereka hanya sekilas mengetahui tentang penyakit kanker serviks, hal ini tidak sejalan dengan hasil penilitian yang dilakukan Sinta, Chinthia, Dwi , 2015 tentang hubungan hubungan tingkat pengetahuan tentang kanker serviks dengan sikap terhadap pemeriksaan papsmear pada pus di puskesmas semanu gunungkidul. penelitian Ayub (2010) yang mengatakan bahwa seseorang yang bekerja akan memiliki persepsi yang positif terhadap suatu tindakan dengan demikian akan termotivasi untuk mau tahu tentang informasi penyakit kanker serviks.
Hasil uji statistik variabel tingkat pendidikan menunjukkan bahwa ada hubungan antara tingkat pendidikan dengan pengetahuan penyakit kanker serviks. Hasil penelitian menunjukkan banyaknya ibu yang memiliki tingkat pengetahuan yang tinggi akan mudah paham ada hubungannya terhadap pengetahuan sejalan dengan penelitian yang dilakukan Utami, Nungky Marcellia (2013) terdapat hubungan yang bermakna antara tingkat pengetahuan tentang kanker serviks dan keikutsertaan dalam melakukan pemeriksaan inspeksi visual asetat $(\mathrm{p}=0,009)$. Hasil penelitian ini sesuai teori yang dikemukakan oleh A.Wawan dan Dewi M (2011) bahwa pendidikan diperlukan untuk mendapat informasi misalnya hal-hal yang menunjang kesehatan sehingga dapat meningkatkan kualitas hidup. Pendidikan wanita yang semakin tinggi menimbulkan kesadaran untuk mengembangkan diri dalam bentuk merintis karir maupun melakukan kegiatan sosial. Chobarunsitti (2007) bahwa tingkat pendidikan merupakan salah satu faktor yang menentukan terhadap terjadinya perubahan prilaku, dimana semakin tinggi tingkat pendidikan berarti telah mengalami proses belajar yang lebih sering dengan kata lain tingkat pendidikan mencerminkan intesitas terjadinya proses belajar. Hasil diatas menunjukkan bahwa ibu yang 
memiliki pendidikan tinggi cenderung memiliki pengetahuan untuk mengetahui tentang penyakit kanker serviks. Dan sejalan dengan hasil penelitian Sinta, Chinthia, Dwi , 2015 berdasarkan uji statistik Chisquare memperlihatkan bahwa terdapat hubungan yang signifikan antara tingkat pengetahuan tentang kanker serviks dengan sikap terhadap pemeriksaan papsmearkarena mempunyai nilai $\rho$ value $=0,003 \quad(\rho<0,05)$. Hal yang sama dengan hasil penelitian yang Lesse Maharsie, . Indarwati, 2012 dilakukan terdapat hubungan antara pengetahuan tentang kanker serviks dengan keikutsertaan ibu melakukan IVA Test di Kelurahan Jebres Surakarta. Hal ini didukung oleh penelitian Aksu, Kucuk\& Duzgun (2011) bahwa pengetahuan dihubungkan dengan adanya minat dari ibu serta adanya dukungan dari tenaga kesehatan dalam melakukan intervensi keperawatan dalam hal ini pengetahuan tentang kanker serviks. Penelitian menurut Birgit et al (2004) menyatakan pengetahuan atau sikap dapat menolong mengurangi pemahaman yang salah, meningkatkan kooperatif dan kualitas perawatan pada ibu ibu.

Hasil uji statistik variabel suku, penderita menunjukkan bahwa ada tidak hubungan antara suku, penderita dengan pengetahuan penyakit kanker serviks. Hasil penelitian menunjukkan banyaknya ibu yang berasal dari daerah jawa. Didapatkan paling banyak adalah dari daerah di luar jawa, terutama daerah pinggiran dan pedesaan. Hal ini dikarenakan banyak rumah sakit di daerah yang belum lengkap fasilitas kesehatan sehingga memungkinkan penangannya belum optimal.

\section{KESIMPULAN}

Berdasarkan hasil penelitian dan pembahasan tentang gambaran tingkat pengetahuan ibu tentang penyakit kanker serviks di wilayah Jakarta Timur, dapat disimpulkan sebagai berikut Ibu ibu yang ada di wilayah Jakarta Timur berdasarkan metode kuesioner dari jumlah responden sebanyak 103 orang, dengan sebaran isi kuesioner terdiri dari usia,status pernikahan, pekerjaan, pendidikan, penderita, suku, dan pengetahuan di wilayah Jakarta Timur tahun 2019. Kuesioner ini sudah dilakukan uji validitas dan reabilitas. Dari karakteristik isi kuesioner factor yang paling berhubungan dalam tingkat pengetahuan adalah pendidikan dengan $r$ : 0,00 lebih kecil dari 0,05 yang artinya pendidikan memiliki hubungan yang lebih dengan pengetahuan, dibandingkan dengan karakterik lainnya, oleh karena itu tingkat pendidikan ibu akan 
berpengaruh pada pengetahuan ibu sehingga dapat membantu perawat dalam memberikan edukasi tentang penyakit kanker serviks di wilayah Jakarta Timur.

\section{SARAN}

Penelitian lebih lanjut dapat mengembangkan model layanan keperawatan berbasis teknologi dan kolaborasi antara institusi dan profesi lain untuk identifikasi lebih cepat dari insiden penyakit serviks, mulai dari fase promotif, fase kuratif dan rehabilitasi.

\section{UCAPAN TERIMA KASIH}

Peneliti mengucapkan terimakasih kepada responden yang telah berpartisipasi dalam penelitian ini.

\section{DAFTAR PUSTAKA}

Ali, F., Kuelker, R., \& Wassie, B (2012). Understanding cervical cancer in the context of developing countries. Annals of tropical medicine and public health.5(1): 3-15

Andrijono (2012), kanker serviks. Ed. 4. Jakrta: Devisi Onkologi, Departemen Obtetri Ginekologi Fakultas Kedokteran Universitas Indonesia.

Artiningsih, Ninik (2011).Hubungan Antara Tingkat Pengetahuan Dan Sikap Wanita Usia Subur Dengan Pemeriksaan Inspeksi Visual Asam
Asetat Dalam Rangka Deteksi Dini Kanker Cerviks (Di Puskesmas Blooto Kecamatan Prajurit Kulon Mojokerto). Masters thesis, Universitas Sebelas Maret.

Ayub, N. (2010). The relationship between work motivation and job satisfaction. Journal of Psychology, 81, 332-347

Birgit, R., at al .(2004). Do maternity care provider groups have different attitudes towards birth. Jounal of Obstetrics and Gynaecology, 111,1388-1393

Casey, C., Chen, L., \& Rabow, M. W. (2011). Symptom management in gynecologic malignancies. Expert Review Of Anticancer Therapy, 11(7), 1077-1089. doi: 10.1586/ERA. 11.83.

Chobaruinsitti, S. (2007). Effects of selfefficiacy enhancement early ambulation on patients pasca abdominal surgery recovery at phaphuttabath hospital saraburi. Retrieved from http//.emedicine.com

Dharma. K.K (2011), Metodologi Penelitian Keperawatan. CV. Trans Info Media : Jakarta

Desen, W(2008), Buku Ajar Onkologi Klinis. Penerjemah Williw Japaries, Ed. 2. Balai penerbit FKUI: Jakarta

Depkes RI. (2017). Angka Kematian Ibu di Indonesia. Retrieved from http://www.depkes.go.id diunduh tanggal 18 Februari 2019 pukul 11.00

Everdingen et all (2007). Prevalence of pain in patients with cancer: a systematic review of the past 40 years. Jounal Annals Of Oncology 18: 1437-1449 
Ella Nurlelawati, Tria Eni Rafika Devi, Imas Sumiat. Faktor-faktor yang berhubungan dengan kejadian kanker serviks di Rumah Sakit Pusat Pertamina Jakarta Tahun 2016 Midwife Journal" Volume 5 No. 01, Jan 2018 pISSN 2477-3441 eISSN 2477-345X www.jurnalibi.org

Fisher, D, J., et all (2010). Anxiety, depresson, and oain: differences by primary cancer. Journal Support Support Xare Cancer 18:801-810

Greer, B. E. (2010). Cervical Cancer. JNCCNThe journal of the National Comprehensive Cancer Network. 8(12): 1387-14160

Hsiao, Chao-Pin (2008). Stress, Symptom Distress, And Symptom SelfManagement In localized Prostate Cancer. Dissertation of the university of Arizona activities. Journal Of Pain and Symptom Management, 31(3), 229-241. doi: 10.1016/j.jpainsymman.2005.07.012

Hidayat , Hasibuan, D.H. , Fitriyati (2014).Hubungan kejadian kanker serviks dengan jumlah paritas di rsud dr. Moewardi tahun 2013.Departemen Obstetri dan Ginekologi Fakultas Kedokteran Universitas Islam Indonesia

Lenz, E. R., Suppe, F., Gift, A. G., Pugh, L. C., \& Milligant, R. A. (1995). Collaborative developmemt of middlerange nuring theories: toward a theory of unpleasant symptoms. ANS Adv Nurs Sci, 17(3), 1-13.

Lesse Maharsie, Indarwati(2012) Hubungan Pengetahuan Ibu Tentang Kanker Serviks Dengan Keikutsertaan Ibu
Melakukan Iva Test Di Kelurahan Jebres Surakarta. Sekolah Tinggi Ilmu Kesehatan 'Aisyiyah Surakarta

Marvin,D.G., Henrique, A.p., Zhinjun, L. J.Lynn,P., Eduardo, B. (2009) symptom distress in advance cancer patients with anxiety and depression in the palliative care setting, Original Article Support Care Cancer 17:573579

McKninney, E. S \& Murray, S. S (2007), Foundation Of Maternal- Newborn Nursing. Elsevier Science Helath Science Division

Monesa, N. (2003). A critical literature review of psychososial effects of cervical cancer, Mini Desertaton, Rand Afrikans University

Myers, J S (2009). A comparison of the Thery of Unplesant Symptoms and the Conceptual Model of ChemotherapyRelated Changes in Cognitive Function. Oncology Nursing Forum . Vol. 36n NO. 1. E1-E10

Nursalam (2007). Manajemen Keperawatan Aplikasi Dalam Praktik Kepertawatan Professional. Edisi 2. Salemba Medika: Jakarta

Notoatmojo, S. (2010)._Metedologi Penelitian Kesehatan. Jakarta: Rineka Cipta Park, S. K., Nancy A. S., Marilyn K. Douglas, DorAnne Donesky-Cuenco \& Viginia Carrieri-Kholman (2012) Symptoms and functional performance un Korean immigrants with asthma or chornic obstructive pulomonary diasese. Heart \& lung 41 (2012) 226-237 
Potter, P.A \& perry, A. G (2009). Fundamental of Nursing. $7^{\text {th }}$ Ed. Elseiver: Singapore

Prue, G., Allen, J., Gracey, J., Rankin, J., \& Cramp, F. (2010). Fatigue and gynaecological cancer patients during and after anticancer treatmen. Journal of Pain and Symptom Management, 39(2), 197-210. doi: 10.1016/j.jpainsymman.2009.06.011.

Riskesdas. (2018). Laporan perkembangan status kesehatan masyarakat Indonesia. Retrieved http://litbang.depkes.go.id/Laporanriskesdas-2010-pdf. diunduh tanggal 18 Februari 2019 pukul 10.00

Spencer, J. V. (2007). Cervical cancer: deadly diaseas and epidemics. New York: Chelsea hpuse publisher.

Stanley, M (2010). Pathology and epidemiologi of HPV infection in females. Gyenecologic Oncology 117:S5-S10

Sugiyono. (2006). Statistika untuk penelitian. Bandung: Alfabeta.

Saraswati, lia karisma (2009) pengaruh promosi kesehatan terhadap pengetahuan tentang kanker serviks dan partisipasi wanita dalam deteksi dini kanker serviks (di mojosongo rw 22 surakarta). Masters thesis, universitas sebelas maret.

Tabano, M., Condosta, D \& Coons, M (2002). Symptoms affecting quality of life on women with gynecologic cancer. Seminars in Ontologi Nursing, 18(3): 223-230

Tilusari S J.(2014). Gambaran pengetahuan dan sikap wanita pekerja seksual tidak langsungdi hotspot jalan tuanku tambusai kecamatan suka jadi pekanbaru terhadap pap smear dan Inspeksi Visual Asetat sebagai deteksi dini canker serviks. Pekanbaru: FK universitas Riau; 2014

Wang, S. S., Carreon, J. D., Gomez, S. L \& Devesa, S.S (2010). Cervical cancer incidence among 6 Asian ethnic groups in the United States, 1996 Through $2004 . \quad$ Cancer. Doi: 10.1002/cncr.24842:949-952

Wardhani, Siti Moetmainnah, Noor Yazid(2012). Pengetahuan tentang factor resiko, prilaku deteksi dini dengan inspeksi visual asam asetat ( IVA) pada wanita di kecamatan bogor tengah kota bogor. Bandung Meeting on Global Medicine \& Health (BaMGMH). P-ISSN 2597$\underline{5013}$ |E-ISSN 2597-50

Utami, Nungky Marcellia (2013). Hubungan Tingkat Pengetahuan Dengan Perilaku Deteksi Dini Kanker Serviks Pada Pasangan Usia Subur Di Wilayah Kerja Puskesmas Sangkrah, Kelurahan Sangkrah, Kecamatan Pasar Kliwon, Surakarta. Jurnal kedokteran Universitas Muhammadiyah Semarang. ISSN 23018585 